\section{Primary associates to 20 verbs connoting violence}

\author{
RUSSELL G. GEEN and DAVID STONNER \\ University of Missouri, Columbia, Missouri 65201
}

Experiments on human aggression occasionally involve word-association measures in which the emission of words connoting aggression, as associates to stimulus words likewise considered to be aggressive, is taken as an indicator of aggressive arousal (e.g., Feshbach, 1961; Geen \& Pigg, 1970; Geen \& Stonner, 1971). One problem that may arise in the use of such measures stems from the possibility that word associations can be affected by variables other than those that purportedly create differences in aggressive arousal. For example, personality variables may bear some relationship to performance on word-association tests. Innes (1971, 1972) has reported that both manifest anxiety and neuroticism play some role in the formation of associates, and Brown (1970) has found that extraversion is likewise correlated with responding to certain types of verbal stimuli. Each of these three personality variables is related in some way to a hypothetical underlying dimension of arousal or activation (Eysenck, 1967). Performance on word-association measures may therefore be susceptible to individual differences in overall arousal level, a possibility that should be heeded by anyone who would use association scores as indicators of aggressive arousal. At the very least, experimenters who utilize such a methodology should have some associative norms for words connoting aggression and violence. If a response given by most subjects in a certain experimental condition happens also to be a common associate of the verbal stimulus presented, it cannot confidently be taken as evidence of a treatment effect. Unfortunately, the associative norms available in the published literature do not contain lists of associates for words having strong general aggressive connotations (e.g., Palermo \& Jenkins, 1964). The work reported in this paper was undertaken in order to develop a set of associative norms for 20 words having strong aggressive implications, based on responses given by members of the general population from which experimental samples are drawn-University undergraduates.

\section{METHOD}

The list of stimulus words consisted of 26 verbs. Of these, 11 were taken from a word list originally produced by Gellerman

This research was supported by an NSF research grant to the first author. David Stonner is now at Oakland University, Rochester, Michigan.
(1956) and subsequently used in the experiments on aggression cited in the previous paragraph. Of the 11,5 have obvious connotations of aggression and violence (choke, massacre,

Table 1

Examples of "Violent" Verbs and Dominant Associates

\begin{tabular}{|c|c|c|c|}
\hline \multicolumn{2}{|l|}{ Males } & \multicolumn{2}{|l|}{ Females } \\
\hline \multicolumn{4}{|c|}{ CHOKE } \\
\hline Strangle & 27 & Strangle & 32 \\
\hline Throat & 5 & Cough & 12 \\
\hline Cough & 4 & Throat & 6 \\
\hline Car & 4 & Neck & 5 \\
\hline Death & 4 & Gag & 4 \\
\hline Neck & 3 & Food & 4 \\
\hline Gag & 3 & Car & 2 \\
\hline Kill & 2 & Kill & 2 \\
\hline Hand & 2 & Pain & 2 \\
\hline Breath & 2 & Rope & 1 \\
\hline \multicolumn{4}{|c|}{ MASSACRE } \\
\hline Indians & 24 & Indians & 29 \\
\hline Kill & 16 & Kill & 11 \\
\hline Slaughter & 6 & Blood & 8 \\
\hline Blood & 6 & Murder & 5 \\
\hline Annihilate & 3 & Slaughter & 4 \\
\hline Death & 2 & War & 3 \\
\hline Murder & 2 & Destroy & 2 \\
\hline Attack & 2 & Death & 2 \\
\hline Destroy & 1 & Army & 1 \\
\hline War & 1 & Brutal & 1 \\
\hline \multicolumn{4}{|c|}{ MURDER } \\
\hline Kill & 46 & Kill & 45 \\
\hline Death & 7 & Death & 8 \\
\hline Gun & 4 & Blood & 5 \\
\hline Blood & 1 & Gun & 3 \\
\hline Crime & 1 & Weapon & 2 \\
\hline Law & 1 & Crime & 2 \\
\hline Strangle & 1 & Shoot & 1 \\
\hline Trial & 1 & Wrong & 1 \\
\hline Weapon & 1 & Hate & 1 \\
\hline Felony & 1 & Stab & 1 \\
\hline \multicolumn{4}{|c|}{ STAB } \\
\hline Knife & 49 & Knife & 60 \\
\hline Blood & 7 & Kill & 7 \\
\hline Kill & 5 & Blood & 5 \\
\hline Wound & 4 & Wound & 4 \\
\hline Death & 2 & Back & 1 \\
\hline Puncture & 1 & Cut & 1 \\
\hline Back & 1 & Heart & 1 \\
\hline Stick & 1 & Murder & 1 \\
\hline Thrust & 1 & Hurt & 1 \\
\hline Attack & 1 & Job & 1 \\
\hline \multicolumn{4}{|c|}{ TORTURE } \\
\hline Pain & 23 & Pain & 23 \\
\hline Hurt & 12 & Hurt & 14 \\
\hline Rack & 5 & Chamber & 5 \\
\hline Kill & 2 & Punish & 3 \\
\hline Punish & 2 & War & 3 \\
\hline Cruel & 1 & Cruel & 3 \\
\hline Chamber & 1 & Prison & 1 \\
\hline Blood & 1 & Scream & 1 \\
\hline Burn & 1 & Burn & 1 \\
\hline Sadism & I & Suffer & 1 \\
\hline
\end{tabular}


murder, stab, torture) and 6 have fewer such connotations (wash. travel, walk, relax, sleep, listen). The remaining 15 verbs were taken from popular fiction out of contexts describing violent action (punch, kill, attack, assassinate, mangle, slaughter, kick, beat, stomp, smash, annihilate, destroy, fight, strangle, as $\times$ ault).

The list given to the subject consisted of the 26 verbs printed in a column, with a blank space after each. Complete counterbalancing for order of appearance of the words was not feasible with so many stimulus words, but some control for order effects was attained by giving the terms in 10 different randomized orders. The ten different lists were distributed approximately equally among subjects.

Instructions were given by means of a cover sheet on which the subject also indicated his (her) age, sex, and class at the University. The subject was told specifically not to identify himself (herself) by name. The subject was told to write the first word that came to mind as a response to each of the words on the list, to give only one response to each word, and to work as rapidly as possible. Subjects were also asked not to skip words and not to refer back to responses given to previous items on the list. The subject was also informed that there were no "right" or "wrung" associates to any item and was reminded of his (her) complete anonymity.

The list was given to 198 males and 219 females enrolled in undergraduate classes at the University of Missouri. The results obtained from seven male and eight female graduate students were dropped from the sample, leaving a total of 191 male undergraduates and 211 female undergraduates on whose responses the norms are based. The median age of the males was 19.3 years, and that of the females was 18.8 years.

\section{RESULTS}

The 10 terms given most often as primary associates of each of the 26 stimulus items were considered to represent the dominant associates to those words. Space does not permit a presentation of the entire list; however, the data pertaining to the five "violent" verbs originally used by Gellermann (1956) are listed as an example in Table 1. Copies of the entire list are available free of charge from the first author. Responses to each verb are given as a percent of all responses to that word.

\section{REFERENCE NOTE}

1. Gellermann, S. The effects of experimentally induced aggression and inhibition on word-association sequences. Unpublished PhD dissertation. University of Pennsylvania, 1956.

\section{REFERENCES}

Brown, W. P. Individual differences in associating to neutral and emotional words. Journal of Consulting and Clinical Psychology, 1970, 34, 33-36.

Eysenck, H. J. The biological basis of personality. Springfield, III: Thomas, 1967

Feshbach, S. The stimulating versus cathartic effects of a vicarious aggressive activity. Journal of Abnormal and Social Psychology, 1961, 63, 381-385.

Geen, R. G., \& Pigg, R. Acquisition of an aggressive response and its generalization to verbal behavior. Journal of Personality and Social Psy chology, 1970, 15, 165-170.

Geen, R. G. \& Stonner, D. Effects of aggressiveness habit strength on behavior in the presence of aggression-related stimuli. Journal of Personality and Social Psychology, 1971. 17, 149-153.

Innes, J. M. Word association, associative structure, and manifest an xiety. British Journal of Psy chology, 1971, 62, 519-525.

Innes, $J$. M. The relationship of word-association commonality response set to cognitive and personality variables. British Journal of Psy chology, 1972, 63, 421-428.

Palmero, D. S., \& Jenkins, J. J. Word association norms: Grade school through college. Minneapolis: University of Minnesota Press, 1964. 